\title{
Inductive instructional approach, career aspiration and noble values in history
}

\author{
Mohd Razimi Husin ${ }^{1}$, Hishamuddin Ahmad ${ }^{2}$, Ismail Yusuf Panessai ${ }^{3}$, Norliza Abdul Majid ${ }^{4}$, \\ Agus Lokman Sulam 5 \\ ${ }^{1,2,3,4}$ Department of Educational Psychology, Universiti Pendidikan Sultan Idris, Malaysia \\ ${ }^{5}$ Maahad Al-Islah, Malaysia
}

\section{Article Info}

Article history:

Received Dec 3, 2019

Revised Feb 8, 2020

Accepted Feb 23, 2020

\section{Keywords:}

Career aspiration

History subjects

Inductive approach

Noble values

\begin{abstract}
This paper presents inductive instructional approach, career aspirations and noble values in History. In the 21st century there is still History teachers emphasize the only cognitive aspects of student learning, but still have little to do with everyday life, career aspirations and noble values. This study has developed a review list of learning experiences on specific learning content that takes into account inductive approach, career aspirations and noble values of History subject. Finally, this study examines the effectiveness of the learning that emphasize on the inductive approach, career aspirations and noble values. This study uses a qualitative approach supported by quantitative data involving four stages namely library studies, observations, expert suggestions and quasi-experiments. 30 teachers and 60 students were selected through purposeful sampling. The results show that mean inductive learning experiences, career aspirations and noble values in the subject is higher than the learning with other method. The Inductive-directed delivery approach showed a mean increase of 1.15 in students associate with classroom activities. The results also show that an increase of mean 1.5 and 0.35 in career aspirations and noble values. This study has revealed a checklist of learning experiences, career aspirations and noble values that beneficial to all educators.
\end{abstract}

This is an open access article under the CC BY-SA license.

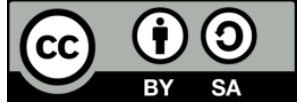

\section{Corresponding Author:}

Mohd Razimi Husin,

Department of Educational Psychology,

Universiti Pendidikan Sultan Idris,

35900 Tanjung Malim, Perak, Malaysia.

Email: razimi@fpm.upsi.edu.my

\section{INTRODUCTION}

Lesson contents and learning experiences are inadequate without regard to students learning needs for daily or future use. 21 st century education emphasizes on learning for life that should apply of real-life learning experience [1]. Areas of academic development should impact life. A learning experience comprises several factors and understanding them becomes a crucial first step in developing engaging learning experiences, considering how learning is no longer always a passive "absorb what is told/what you read" exercise [2]. Individuals learn in different ways using several learning styles, but teachers may not always share material and learning experiences that match students' learning preferences [3]. A previous study indicated that students must have the ability to analyze in solving everyday problems [4].

Previous studies on non-technical skills conducted nationally and internationally have given rise to many skills that can make them employable. The study focused on professional perspectives on non-technical skills that were considered important that could be emphasized in the curriculum [5-6]. The Malaysian 
Education Development Plan 2013-2025 plans to improve the quality of education delivery. Generally, the policies in the implementation of all types of education, whether domestic or international, emphasize physical, emotional, spiritual and intellectual development so that students can get to the highest level of education to enable them to find jobs and life does not depend on others [7]. In order to ensure that this strategic plan achieves its goals, the focus is on a number of areas including Education and Training. Emphasis is also placed on enhancing the ability and growth of youth in employment and entrepreneurship.

One of inductive instructional approach is to implement cooperative learning. It was also found from the teachers that students who work in the cooperative learning groups were more engaged, more responsible in completing group assignments and more organized while working in their respective groups [8]. In a recent paper [9], the authors point to the four challenges that the 21 st century will bring (global interdependence, increasing number of democracies, creative entrepreneurs and the growing importance of interpersonal relationships) and how cooperation plays a central role and how the tools offered by the cooperative learning will help meeting these challenges.

Students in the upper secondary are required to take core subjects from form one through form five. History is one of the core subjects of all areas of science or humanity. A study found that History teachers emphasize the only cognitive aspects of student learning, but still have little to do with everyday life, career aspirations and noble values [10-16]. The findings of a study [17], found that the teaching of History subjects was boring. According to researchers [18-21], have found that aspects of learning approaches need to be applied with a variety of approaches and techniques involving environment, emotion, sociology, physiology and psychology [22]. Whereas the learning techniques to be developed should be closely related to the student's actual situation [17, 23-24]. Teachers' approaches that link with daily life, career aspirations and noble values are important to make the teaching and learning process more effective, as well the information and skills provided can be leveraged when students are out of school.

This paper present content and learning experiences related to the everyday needs, career aspirations and strategist values in History subject. This study uses mixed method in developing a review list of learning experiences, identifying appropriate sub-topics for formulating inductive lesson plans and examining the effectiveness of the learning that emphasize on the inductive approach, career aspirations and noble values in History. The study showed that mean inductive learning experiences, career aspirations and noble values in the subject is higher than the learning with other method. The Inductive-directed delivery approach showed the mean increase in students associate with classroom activities, career aspirations and noble values. This study has revealed teaching plans that includes of learning experiences, career aspirations and noble values that will beneficial to all educators to practice in the classroom.

\section{RESEARCH METHOD}

This study used qualitative and quantitative approaches involving library studies, observations, expert suggestions and quasi-experiments analyzed using Nvivo and SPSS software. This study is a design and development study refer to several implementations of the ADDIE (Analysis, Design, Development, Implement, and Evaluate) model and Nominal Group Technique (NGT) approach. NGTs are used for the process of promoting and generating ideas on issues such as those involving assessment of a curriculum [25]. This technique can be used to measure a product that has been developed. ADDIE involves three main phases namely the analysis, the design and development, and the testing, whereas NGT involves the expert recommendation used in Design and Development Research (DDR) module study. But this study did not exactly follow these models and techniques. It just follows a few sections or ideas. The first act of this study is getting a checklist of learning experiences on learning content that takes into account the required activities, career aspirations and noble values of the subject. Build the checklist involved experts of 30 experienced teachers. All points of view are taken as a learning approach called Inductive directed delivery approach. Those experts brainstormed on learning experiences, career aspirations and noble values of form 1 History subjects [26]. The findings to confirm the study's need of appropriate sub-topics for formulating inductive lesson plans in History subjects. The inductive lesson plan requires the validity of the 5 experts in the field. Build the checklist of inductive learning experiences, career aspirations and noble values involved experts of 30 experienced teachers. The level of sub-topic's need was assessed using five scale $(5,7,18,23$, 25) by experts based on the relationship between the learning experience and the daily life of the students as shown in Table 1. 
Table 1. The checklist of inductive learning experiences, career aspirations, noble values and its level involved experts of 30 experienced teachers

\begin{tabular}{ccccc}
\hline $\begin{array}{c}\text { Title and } \\
\text { Sub-title }\end{array}$ & $\begin{array}{c}\text { Learning } \\
\text { Experiences }\end{array}$ & Level & Career & Noble Values \\
\hline $\mathrm{x}$ & $\mathrm{x}$ & $\mathrm{x}$ & $\mathrm{x}$ & $\mathrm{z}$ \\
& $\mathrm{y}$ & & $\mathrm{y}$ & $\mathrm{y}$ \\
$\mathrm{z}$ & & $\mathrm{z}$ & $\mathrm{z}$ \\
\hline
\end{tabular}

Then, researchers choose a high-level sub-topic that is four and above based on scale given by experts. the lesson plan based on three elements, which are inductive learning experiences, career aspirations and noble values has been developed. The design table of lesson plan as shown in Figure 1.

\begin{tabular}{|c|c|c|c|}
\hline \multicolumn{4}{|c|}{ Teaching Plan } \\
\hline Subject: & $\begin{array}{l}\text { Theme: } \\
\text { Topic: }\end{array}$ & Form: & Date / Day / Time: \\
\hline $\begin{array}{l}\text { Learning Standard } \\
\text { Code: }\end{array}$ & Moral / Noble Values: & \multicolumn{2}{|c|}{$\begin{array}{l}\text { Curriculum Structure Relationships: } \\
X \text { and Career Aspiration }\end{array}$} \\
\hline Learning objective: & \multicolumn{3}{|l|}{ Success Criteria: } \\
\hline Key Concepts / Events: & & Source & \\
\hline
\end{tabular}

\begin{tabular}{|l|l|l|}
\hline \multicolumn{2}{|c|}{ Teaching Framework } & Impact / Reflection \\
\hline & & \\
Beginner Activity & 1. & \\
(5 minutes) & 2. & \\
& & \\
Main Activity & 1. Field Activities - & \\
(45 minutes) & 2. Activity (Group) & \\
& 3. Individual Field Activity Report (In the classroom) & \\
\hline Plenary Activities & 1. \\
(10 minutes) & 2. & \\
\hline
\end{tabular}

Figure 1. Table of IDDA Lesson plan

Finally, a quasi-experiment was carried out which involves 30 samples of 15 students in a group that will use different teaching methods such as IDDA and regular teaching. The experiment was performed twice per group, which was cross sectioned into two groups against the two methods [27-28]. Experimental data using perception surveys were analyzed using Nvivo and SPSS software. The data were pre and post test data, and perceptual survey data. The method of computing the collected survey data is shown in (1).

$$
\frac{\Sigma G 1 T 1+\Sigma G 2 T 2}{N}-\frac{\Sigma G 1 T 2+\Sigma G 2 T 1}{N}=\text { fmean }
$$

\section{RESULTS AND DISCUSSION}

Based on observations made on History subjects to support the literature review, it shows that most teachers did not plan their learning according to the needs of the students [29-30]. The extent to which these real needs are used in everyday life needs to be further discussed. The first finding is presented with a checklist of learning experiences on specific learning content that takes into account inductive approach, career aspirations and noble value of History subject. The finding is then presented with an Identify appropriate sub-topics for formulating inductive lesson plans in History subjects. Finally, assessing the effectiveness learning emphasizes on the inductive approach, career aspirations and noble values for the specific learning content is presented.

\subsection{Developed a checklist of learning experiences on specific learning content that takes into account inductive approach, career aspirations and noble values of history subject}

The construction of checklists requires in-depth study of selected subjects that takes into account the inductive approach, career aspirations and noble values. The results were obtained through expert opinion using Nominal Group Techniques (NGTs) in which they have contributed to the issue by building a list of 
History learning experiences career aspirations and noble values (Table 2). The contents of the checklist are titles, sub-titles, learning experiences, level of need, employment and strategic value. The level of need is assessed by experts based on the relationship between the learning experience and the daily life of the students.

Table 2. The list of experiences of learning history focusing on inductive approach, career aspirations and noble values

\begin{tabular}{clllll}
\hline Title and Sub-title & Learning Experiences & Career & & Noble Values \\
\hline Early World & Explore Development & a. & Agriculture & a. & Appreciate and Grateful \\
Civilization & /Agriculture Location & b. & Archaeologist & b. & Appreciate Heritage of Environment \\
Locations & & & & c. & Acceptance of Equations and Differences \\
\hline
\end{tabular}

\subsection{Appropriate sub-topics for formulating inductive lesson plans in history}

There are a number of sub-topics in form 1 History subject that are appropriate for developing Inductive Directed Delivery Approach (IDDA) lesson plans according to the recommendations of experts and certified by 5 experts in the field. The sub-topics are as Table 3 and Figure 2.

Table 3. The sub-topics for formulating inductive lesson plans in History

\begin{tabular}{|c|c|c|c|}
\hline Sub-topics & Learning Experiences & Career & Noble Values \\
\hline $\begin{array}{l}\text { Architecture of Rome } \\
\text { Civilization } \\
\text { Chapter } 6\end{array}$ & $\begin{array}{l}\text { Explore the school's } \\
\text { colosseum }\end{array}$ & a. Architecture & $\begin{array}{l}\text { a. Diligence } \\
\text { b. Creatives } \\
\text { c. No damage to public property }\end{array}$ \\
\hline $\begin{array}{l}\text { Public Exam of Chinese } \\
\text { Civilization } \\
\text { Chapter } 7\end{array}$ & $\begin{array}{l}\text { Explore the exam } \\
\text { statement boards }\end{array}$ & a. Teacher & $\begin{array}{l}\text { a. Diligence } \\
\text { b. Imitate the success of others } \\
\text { c. Not jealous of others'success }\end{array}$ \\
\hline
\end{tabular}

\begin{tabular}{|c|c|c|c|}
\hline \multicolumn{4}{|c|}{ Teaching Plan } \\
\hline $\begin{array}{l}\text { Subject: } \\
\text { History }\end{array}$ & $\begin{array}{l}\text { Theme: Architecture of } \\
\text { Rome Civilization } \\
\text { Topic: The Rise of Greek } \\
\text { and Roman Civilizations }\end{array}$ & $\begin{array}{l}\text { Form: } \\
\text { Form } 1\end{array}$ & Date / Day / Time: \\
\hline $\begin{array}{l}\text { Learning Standard } \\
\text { Code: } \\
6 \text { TP } 2 \text { and } 4\end{array}$ & $\begin{array}{l}\text { Moral / Noble Values: } \\
\text { 1. Diligence } \\
\text { 2. Creatives } \\
\text { 3. Be grateful } \\
\text { 4. No damage to public } \\
\text { property }\end{array}$ & \multicolumn{2}{|c|}{$\begin{array}{l}\text { Curriculum Structure Relationships: } \\
\text { Creativity and innovation, ICT, Value Added Skills } \\
\text { and Career Aspiration }\end{array}$} \\
\hline Learning objective: & \multicolumn{3}{|l|}{ Success Criteria: } \\
\hline \multicolumn{2}{|c|}{$\begin{array}{l}\text { Key Concepts / Events: } \\
\text { Colosseum and building construction }\end{array}$} & \multicolumn{2}{|c|}{$\begin{array}{l}\text { Source: } \\
\text { Selected location, Activity / Workbook, marker pen, } \\
\text { sketch paper }\end{array}$} \\
\hline
\end{tabular}

\begin{tabular}{|c|c|c|}
\hline \multicolumn{2}{|r|}{ Teaching Framework } & Impact / Reflection \\
\hline $\begin{array}{l}\text { Beginner Activity } \\
\text { (5 minutes) }\end{array}$ & $\begin{array}{l}\text { 1. Sharing activity on interesting buildings. } \\
2 \text {. Pupils conclude the above discussion by relating the } \\
\text { function of the building. }\end{array}$ & \\
\hline $\begin{array}{l}\text { Main Activity } \\
\text { (45 minutes) }\end{array}$ & $\begin{array}{l}\text { 1. Field Activities - Explore the school's colosseum. } \\
\text { 2. Sketch Activity (Group) } \\
\text { - Group members play } \\
\text { - The school's colosseum building } \\
\text { - Plans / writes the functions of the school } \\
\text { colosseum } \\
\text { - Factors of ability to build a school colosseum } \\
\text { 3. Individual Field Activity Report (In the classroom) }\end{array}$ & \\
\hline $\begin{array}{l}\text { Plenary Activities } \\
\text { (10 minutes) }\end{array}$ & $\begin{array}{l}\text { 1. Spontaneous Quiz Architecture of Roman } \\
\text { Civilization } \\
\text { 2. Pupils are given the opportunity to complete a } \\
\text { home report within a week before being evaluated. }\end{array}$ & \\
\hline
\end{tabular}

Figure 2. Example of IDDA Lesson Plan

3.3. Effectiveness learning emphasize on the inductive approach, career aspirations and noble values

This study showed that there was a mean increase in perceptual approach perceptions of items 2 (Understanding lessons), 4 (Associating classroom activity with lesson content) and 5 (Expanding group discussion) as Table 4, Table 5, Table 6 and Table 7. 


\begin{tabular}{ll}
\multicolumn{2}{c}{ Table 4. Mean of X approach } \\
\hline \multicolumn{1}{c}{ Perception } & Mean \\
\hline Understand the lesson & 3.90 \\
Associate classroom activities with lesson content & 3.61 \\
Engage in group discussions & 2.90 \\
\hline
\end{tabular}

Table 5. Mean of inductive directed delivery approach (IDDA)

\begin{tabular}{ll}
\hline \multicolumn{1}{c}{ Perception } & Mean \\
\hline Understand the lesson & 4.49 \\
Associate classroom activities with lesson content & 4.76 \\
Engage in group discussions & 3.44 \\
\hline
\end{tabular}

Table 6. Noble values mean

\begin{tabular}{ll}
\hline \multicolumn{1}{c}{ Perception } & Mean \\
\hline Group 1 (x Approach) & 3.86 \\
Group 2 (IDDA Approach) & 4.21 \\
\hline
\end{tabular}

Table 7. Career aspiration mean

\begin{tabular}{ll}
\hline \multicolumn{1}{c}{ Perception } & Mean \\
\hline Group 1 (x Approach) & 1.00 \\
Group 2 (IDDA Approach) & 2.50 \\
\hline
\end{tabular}

\section{CONCLUSION}

The construction of checklists have contributed to the issue by building a list of History learning experiences, career aspirations and noble values. An example of learning experiences is exploring the locations of development and agriculture, the school's Colosseum and the exam statement boards. There are a number of sub-topics in form 1 History subject that are appropriate for developing Inductive Directed Delivery Approach (IDDA) lesson plans according to the recommendations of experts such as Early World Civilization Locations, Architecture of Rome Civilization and Public Exam of Chinese Civilization. The results also show that an increase of mean in Inductive-directed Delivery Approach, career aspirations and noble values.

School-based learning experiences need to be designed so that information and skills gained can be used directly. An Inductive Directed Delivery Approach (IDDA) can greatly benefit students in understanding the content of learning. Out-of-class activities created and associated with past historical events help students easily receive information, and similarly, this approach gives students confidence to present learning content after a discussion session with peers. Therefore, an IDDA can be accepted as an approach to school-based learning to meet the requirements of the Ministry of Education Malaysia (MOE) which is responsible for education to deliver learning content in the most beneficial manner to students.

Teacher also need to move from the old-fashioned approach to pressures appropriate to 21 st century education. This study clearly demonstrates the usual methods without engaging in organized activities that make students feel less motivated and less aware of their learning content. Inductive Directed Delivery Approach (IDDA) makes teaching and learning of history is not boring. Therefore, practicing History teachers using this approach is expected to reduce student fatigue in the classroom. Environmental, emotional, sociological, physiological and psychological aspects need to be incorporated into learning approaches and techniques. The student's actual condition is a reflection of the planning and construction of student learning methods and techniques.

\section{ACKNOWLEDGEMENTS}

This paper is based on the research project entitled Modul Pendekatan Penyampaian Induktif Terarah, Nilai Strategis dan Aspirasi Kerjaya dalam Mata Pelajaran Sejarah. The authors would like to extend their gratitude to the Research Management and Innovation Centre (RMIC), Sultan Idris Education University (UPSI) for the Education Innovation Grant (Geran Inovasi Pendidikan) 2019 that helped fund the research.

\section{REFERENCES}

[1] O. Goethe, "Learning experiences in real life," in Gamification Mindset, pp. 14-20, 2019. 
[2] R. Sampangi and A. Siegel, "Designing Engaging Learning Experiences," in the 2019 ACM Conference, pp. 10-18, 2019.

[3] N. Chetty, et al., "Learning styles and teaching styles determine students' academic performances," Journal of Evaluation and Research in Education (IJERE), vol. 8, pp. 25-32, 2019.

[4] J. Jufrida, et al., "The correlation between scientific literacy and science learning achievement at junior high School," International Journal of Evaluation and Research in Education (IJERE), vol. 8, pp. 106-204, 2019.

[5] B. Shola, et al., "The non-technical skills needed by graduates of technical colleges in metalwork technology for future Employment," International Journal of Evaluation and Research in Education (IJERE), vol. 8, pp. 98-106. 2019.

[6] T. Selvam, "Career aspiration among rural undergraduate students," International Research Journal of Human Resources and Social Sciences, vol. 4, pp. 21-27, 2017.

[7] A. Yusoff, et al., "Special education curriculum management learning problems: an early study and innovation needs (in Malay)," in Prosiding International Conference on Early Childhood and Special Education 2011. Pulau Pinang: Universiti Sains Malaysia, pp. 7-14, 2009.

[8] M. Jony, "Exploring the effectiveness of cooperative learning at secondary level in Bangladesh," International Journal of Educational Research Review, vol. 5, pp. 93-99, 2019.

[9] D. Johnson and R. Johnson, "Aprendizaje cooperativo en el siglo XXI," Anales de Psicologia, vol. 30, pp. 841-851, 2014.

[10] M. Husin and H. Ahmad, "Teacher self-measurement of the daily use of lesson content (in Malay)," in Prosiding International Conference on Psychology and Counselling Assessment 2017. Tanjung Malim: Universiti Pendidikan Sultan Idris, pp. 128-131, 2017.

[11] M. Husin, et al., "Learning and Environments Influencing Students' Difficulty Learning in Islamic Education Subjects (in Malay),” Jurnal Penyelidikan Dedikasi, vol 11, pp. 98-111, 2011.

[12] M. Husin, "Exploring the use of digital devices among pupils with learning disabilities," International Journal of Multimedia and its Applications, vol. 9, pp. 75-86, 2017.

[13] M. Husin, et al., "Video application model in learning styles of moral education students in teacher educational institution," International Journal of Engineering and Technology (UAE), vol. 7, pp. 21-26, 2018.

[14] M. Husin, et al., "Making short video and multi-sensory instructional packages for moral education courses in teacher education institutes," Global Journal of Advanced Engineering Technologies and Sciences, vol. 5, pp. 9-18, 2018.

[15] M. Husin and M. Rahman, "Psychology and civilization" in International Conference on Islamic Revealed Knowledge 2018, UPSI, pp. 409-417, 2018.

[16] M. Husin, "Style of learning students difficult to study in islamic education subjects and j-QAF (in Malay), in Unpublished Thesis UPSI, pp. 300-350, 2017.

[17] M. Samsudin and S. Shaharuddin, "Management and administration of Islamic Education in Malaysia (in Malay)," Jebat, vol. 39, pp. 116-141, 2012.

[18] A. Din, "Management and administration of Islamic Education in Malaysia (in Malay)," in Konvensyen Kebangsaan Pendidikan Islam 2011, pp. 450-464, Kuala Lumpur: Universiti Malaya, 2011.

[19] N. Wamba and K. Dunn, "Effective individualized educational plans: Do something special with learning styles," Insights on Learning Disabilities, vol. 6, pp. 1-11, 2009.

[20] O. Kareem, "Islamic education management: Is reality fulfilling expectations? (in Malay)," in Konvensyen Kebangsaan Pendidikan Islam 2011, pp. 1-2, Kuala Lumpur: Universiti Malaya, 2011.

[21] Z. Hussin, et al., "Teaching and learning islamic education for special needs pupils: Implementation and problems (in Malay)," in Prosiding International Conference and Exhibition on Research in Islamic and Arabic Language Education 2011, pp. 9-17, Langkawi: Hotel Awana Porto Malai, 2011.

[22] O. Wijaya and I. Bukhori, "Effect of Learning Motivation, Family Factor, School Factor, and Community Factor on Student Learning Outcomes on Productive Subject," Jurnal Pendidikan Bisnis dan Manajemen, vol. 3, pp. 192-202, 2017.

[23] A. Adnan and W. Jamal, "Special education student prayer requirements and procedures (in Malay)", in Prosiding Persidangan Antarabangsa Pendidikan Khas 2012, pp. 20-27, Melaka: Hotel Mahkota, 2012.

[24] H. Som, "Teaching and Learning Islamic Education in Malaysia: One highlight (in Malay)," in Konvensyen Kebangsaan Pendidikan Islam 2011, pp. 65-71, Kuala Lumpur: Universiti Malaya, 2011.

[25] A. Dobbie, et al., "Using a modified nominal group technique as a curriculum evaluation tool, Family Medicine, vol 36, pp. 402-406, 2014.

[26] 26M. Behrendt \& T. Franklin., "A review of research on school field trips and their value in education", International Society of Educational Research, vol 9, pp 235-245, 2014

[27] W. Widodo, "Assessing the readiness of student learning acitivity and learning outcome," Jurnal Pencerahan, vol. 10, pp. 81-94, Sep 2016.

[28] Z. Taurina, "Student's motivation and learning outcomes: Significant factors in internal study quality assurance system," International Journal for Cross-Disciplinary Subjects in Education, vol. 5, pp. 2625- 2630, 2015.

[29] R. Ishak and R. Jantan, "Review of student perceptions of low school history subjects (in Malay)," Asian Education Action Research Journal (AEARJ), vol. 4, pp. 64-80, 2015.

[30] S. Jaafar and A. Nor, "Implementation of teaching and learning history in schools in Malaysia (in Malay), 1957-1989. Sejarah, vol. 25, pp. 40-57, 2016. 